\title{
EFFECTS OF MANAGEMENT PRACTICES ON GRASSLAND BIRDS:
}

\section{LONG-BILLED CURLEW}

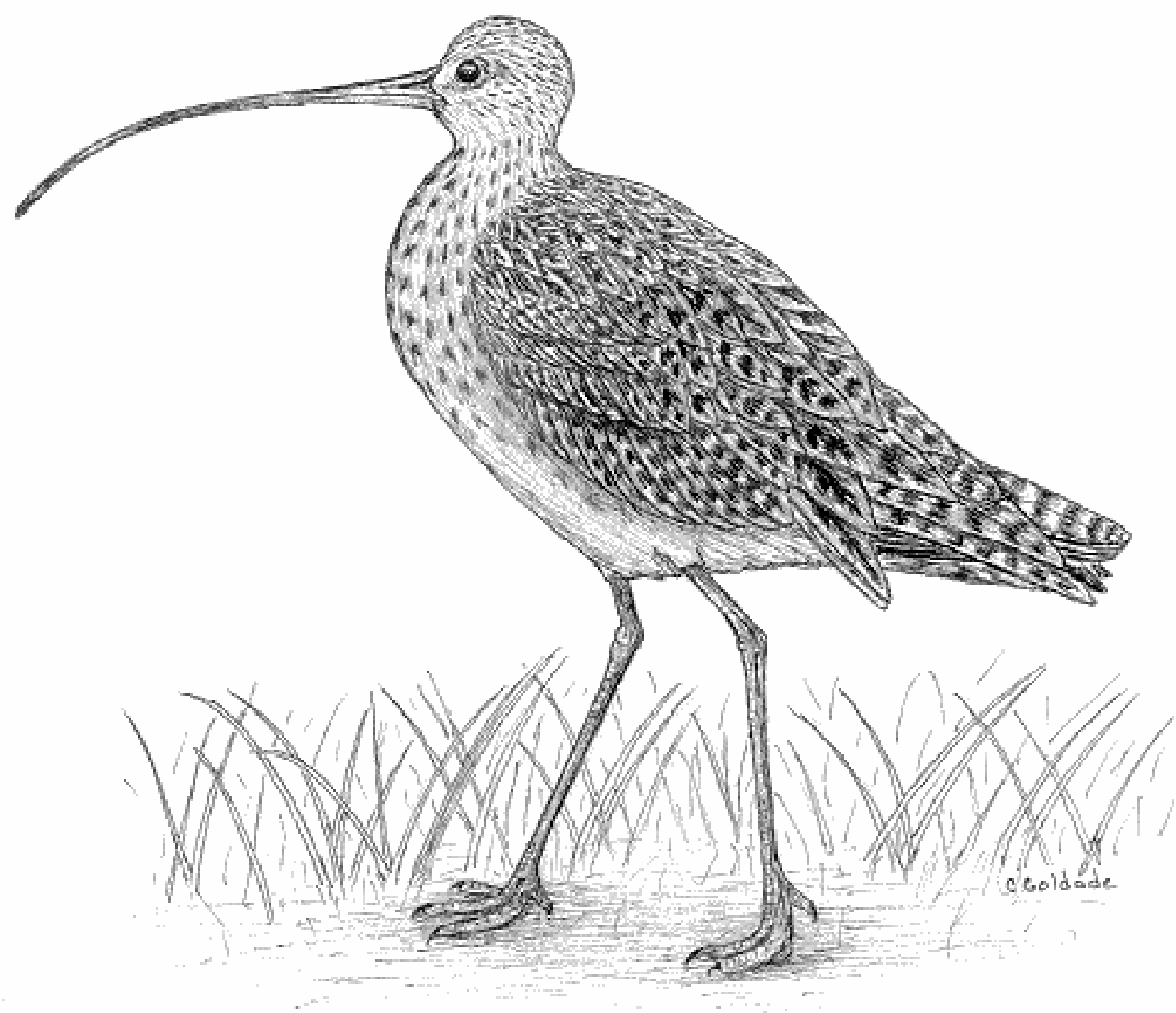

Grasslands Ecosystem Initiative

Northern Prairie Wildlife Research Center

U.S. Geological Survey

Jamestown, North Dakota 58401 
This report is one in a series of literature syntheses on North American grassland birds. The need for these reports was identified by the Prairie Pothole Joint Venture (PPJV), a part of the North American Waterfowl Management Plan. The PPJV recently adopted a new goal, to stabilize or increase populations of declining grassland- and wetland-associated wildlife species in the Prairie Pothole Region. To further that objective, it is essential to understand the habitat needs of birds other than waterfowl, and how management practices affect their habitats. The focus of these reports is on management of breeding habitat, particularly in the northern Great Plains.

Suggested citation:

Dechant, J. A., M. L. Sondreal, D. H. Johnson, L. D. Igl, C. M. Goldade, P. A. Rabie, and B. R. Euliss. 1999 (revised 2002). Effects of management practices on grassland birds: Long-billed Curlew. Northern Prairie Wildlife Research Center, Jamestown, ND. 19 pages.

Species for which syntheses are available or are in preparation:

American Bittern

Mountain Plover

Marbled Godwit

Long-billed Curlew

Willet

Wilson's Phalarope

Upland Sandpiper

Greater Prairie-Chicken

Lesser Prairie-Chicken

Northern Harrier

Swainson's Hawk

Ferruginous Hawk

Short-eared Owl

Burrowing Owl

Horned Lark

Sedge Wren

Loggerhead Shrike

Sprague's Pipit
Grasshopper Sparrow

Baird's Sparrow

Henslow's Sparrow

Le Conte's Sparrow

Nelson's Sharp-tailed Sparrow

Vesper Sparrow

Savannah Sparrow

Lark Sparrow

Field Sparrow

Clay-colored Sparrow

Chestnut-collared Longspur

McCown's Longspur

Dickcissel

Lark Bunting

Bobolink

Eastern Meadowlark

Western Meadowlark

Brown-headed Cowbird 


\section{EFFECTS OF MANAGEMENT PRACTICES ON GRASSLAND BIRDS:}

\section{LONG-BILLED CURLEW}

Jill A. Dechant, Marriah L. Sondreal, Douglas H. Johnson, Lawrence D. Igl, Christopher M. Goldade, Paul A. Rabie, and Betty R. Euliss

Series Coordinator: Douglas H. Johnson

Series Assistant Coordinator: Lawrence D. Igl

Reviewer: Roland L. Redmond

Range Map: Jeff T. Price

Cover Art: Christopher M. Goldade

Major Funding: Prairie Pothole Joint Venture, U.S. Fish and Wildlife Service U.S. Geological Survey

Funding also provided by: U.S. Forest Service The Nature Conservancy

\section{Collaborators:}

Louis B. Best, Iowa State University

Carl E. Bock, University of Colorado

Brenda C. Dale, Canadian Wildlife Service

Stephen K. Davis, Saskatchewan Wetland Conservation Corporation

James J. Dinsmore, Iowa State University

James K. Herkert, Illinois Endangered Species Protection Board

Fritz L. Knopf, Midcontinent Ecological Science Center

Rolf R. Koford, Iowa Cooperative Fish and Wildlife Research Unit

David R. C. Prescott, Alberta NAWMP Centre

Mark R. Ryan, University of Missouri

David W. Sample, Wisconsin Department of Natural Resources

David A. Swanson, Ohio Division of Wildlife

Peter D. Vickery, Massachusetts Audubon Society

John L. Zimmerman (retired), Kansas State University 


\section{ORGANIZATION AND FEATURES OF THIS SPECIES ACCOUNT}

Information on the habitat requirements and effects of habitat management on grassland birds were summarized from information in more than 4,000 published and unpublished papers. A range map is provided to indicate the primary breeding distribution of the species in North America, based on North American Breeding Bird Survey data. The shading on the map represents the average number of individuals detected per route per year. Although birds frequently are observed outside the breeding range indicated, the maps are intended to show areas where managers might concentrate their attention. It may be ineffectual to manage habitat at a site for a species that rarely occurs in an area. The species account begins with a brief capsule statement, which provides the fundamental components or keys to management for the species. A section on range outlines the current breeding distribution of the species in North America, including details on areas that could not be mapped using BBS data. The suitable habitat section describes the breeding habitat and occasionally microhabitat characteristics of the species, especially those habitats that occur in the Great Plains. Details on habitat and microhabitat requirements often provide clues to how a species will respond to a particular management practice. If habitat needs vary appreciably in different parts of the breeding range, those needs are indicated. A table near the end of the account complements the section on suitable habitat, and lists the specific habitat characteristics for the species by individual studies. The table usually provides more details than those provided within the text. A special section on prey habitat is included for those predatory species that have more specific prey requirements. For species exhibiting area sensitivity, details on minimum area requirements are provided. It may be futile to manage a small block of suitable habitat for a species that has minimum area requirements that are larger than the area being managed. The impact of management on the species depends, in part, upon a species nesting phenology, including the length of the nesting cycle and duration of the breeding season, and the tendency to renest after nest failure. Breeding-season phenology provides representative dates of spring arrival and fall departure (and occasionally peak breeding period) for the species in the Great Plains. The duration and timing of breeding will vary from region to region and from year to year. Species' response to management summarizes the current knowledge and major findings in the literature on the effects of different management practices, including burning, mowing, and grazing, on the species. The section on management recommendations complements the previous section and summarizes specific recommendations for habitat management provided in the literature. If management recommendations differ in different portions of the species' breeding range, recommendations are treated separately by region. The literature cited contains references to published and unpublished literature on the management effects and habitat requirements of the species. This section is not meant to be a complete bibliography; a searchable, annotated bibliography of published and unpublished papers dealing with habitat needs of grassland birds and their responses to habitat management is posted at the Web site mentioned below.

This report has been downloaded from the Northern Prairie Wildlife Research Center WorldWide Web site, www.npwrc.usgs.gov/resource/literatr/grasbird/grasbird.htm. It will be updated as necessary. We invite comments and suggestions. Please direct them to Douglas H. Johnson, Northern Prairie Wildlife Research Center, U.S. Geological Survey, 8711 37th Street SE, Jamestown, North Dakota 58401; telephone: 701-253-5539; fax: 701-253-5553; e-mail:

Douglas_H_Johnson@usgs.gov. 


\section{LONG-BILLED CURLEW}

(Numenius americanus)

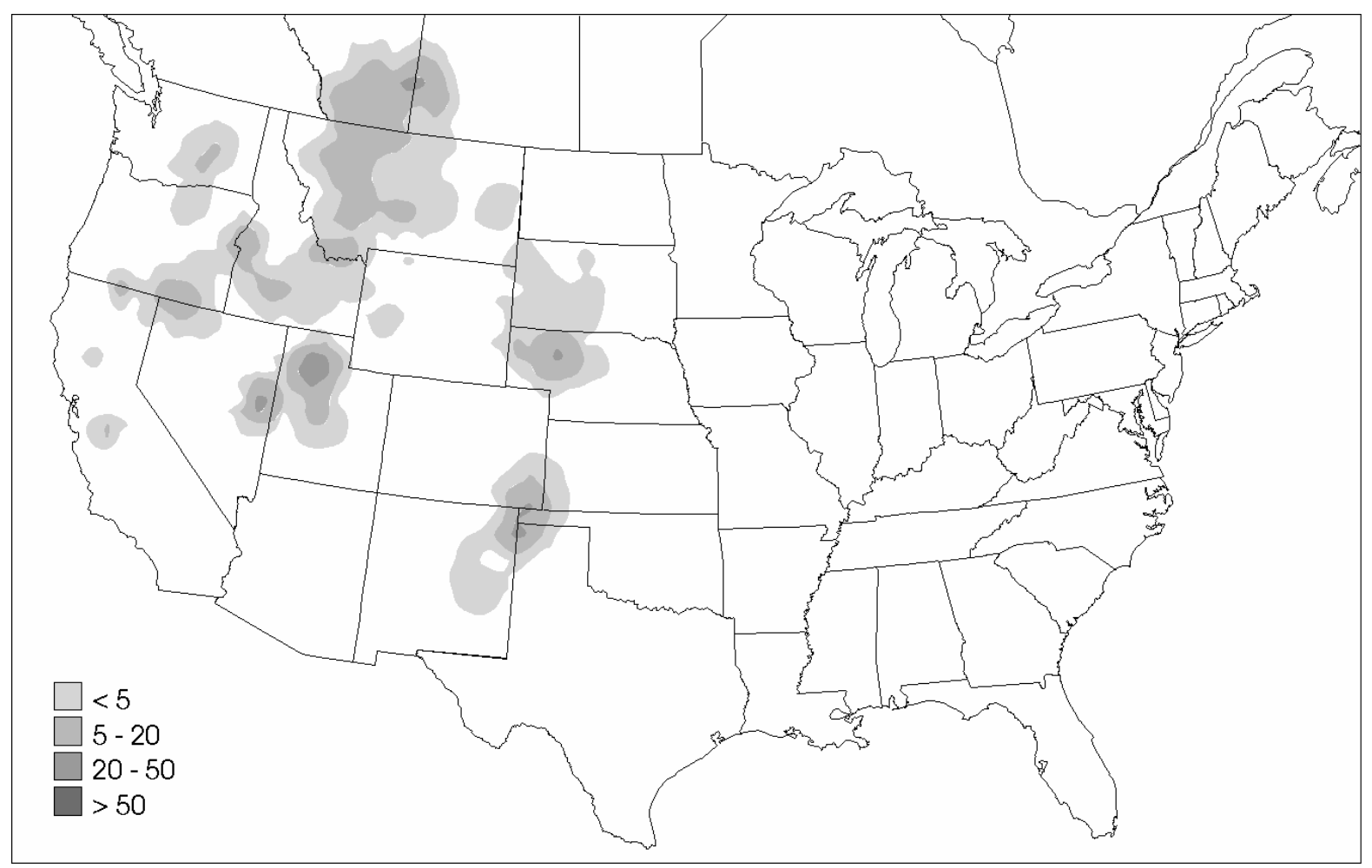

Figure. Breeding distribution of the Long-billed Curlew in the United States and southern Canada, based on Breeding Bird Survey data, 1985-1991. Scale represents average number of individuals detected per route per year. Map from Price, J., S. Droege, and A. Price, The Summer Atlas of North American Birds, Academic Press, 1995.

Keys to management include providing large, open, level to gently rolling grasslands with short vegetation, and tailoring grazing regimes to local conditions.

\section{Breeding range:}

Long-billed Curlews breed from interior British Columbia and southern Alberta through southern Manitoba, south to central California, and east to western North Dakota, central South Dakota, central Nebraska, western Kansas, northeastern New Mexico, and northern Texas (National Geographic Society 1987). (See figure for the relative densities of Long-billed Curlews in the United States and southern Canada, based on Breeding Bird Survey data.)

\section{Suitable habitat:}

Long-billed Curlews use expansive, open, level to gently sloping or rolling grasslands with short vegetation such as shortgrass or recently grazed mixed-grass prairie (Salt and Wilk 1958, Bent 1962, Graul 1971, Stewart 1975, Johnsgard 1980, Bicak et al. 1982, Cochran and Anderson 1987, Shackford 1987, Eldridge 1992). They commonly nest in both wet and dry prairie and in pastures, but rarely nest in hayland, cropland, fallow, or stubble fields (Salt and 
Wilk 1958, Bent 1962, McCallum et al. 1977, Renaud 1980, Cochran and Anderson 1987, Shackford 1994).

Proximity to water may be an important factor in habitat selection (McCallum et al. 1977, Cochran and Anderson 1987, Shackford 1987). In southeastern Colorado, 41\% of 63 Longbilled Curlew observations occurred within $91 \mathrm{~m}$ of standing water, and 68\% of observations were within $403 \mathrm{~m}$ (McCallum et al. 1977). In southeastern Colorado and northwestern Texas, $39 \%$ of 354 curlew observations occurred within $400 \mathrm{~m}$ of stock ponds or irrigation facilities (King 1978). In Utah, nests often were placed near the edges of alkali flats of the Great Salt Lake (Paton and Dalton 1994). Shackford (1987) suggested that a drop in the water table in the panhandle of Oklahoma caused Long-billed Curlews to favor areas near irrigated fields over upland, shortgrass sites. However, in southeastern Alberta, Long-billed Curlews were less common on wet transects (a wet transect was defined as having wetlands intersecting the transect along $>5 \%$ of its length) than on dry transects (Gratto-Trevor 1999). Because curlews are known to return to the same area to nest each year regardless of whether water is still available, curlews may be found nesting far from water if water sources have disappeared (McCallum et al. 1977).

Long-billed Curlews in Colorado used shortgrass, mixed-grass, and weedy areas more than expected based on the availability of those habitats (King 1978). They used agricultural areas (cropland, stubble fields, and bare ground) less than expected based on availability and did not use areas dominated by sand sagebrush (Artemisia filifolia). In northcentral Oregon, areas of shrubs or areas of downy brome (Bromus tectorum) intermixed with patches of Sandberg's bluegrass (Poa sandbergii) were preferred or used in proportion to availability by Long-billed Curlews (Pampush 1980, Pampush and Anthony 1993). Areas of dense forbs, antelope bitterbrush (Purshia tridentata), and bunchgrasses were used in proportion to their availability or were avoided. If bunchgrass habitats were used by adults with broods, they always were contiguous with downy brome areas that were being used as nesting sites.

Long-billed Curlews in Nebraska used areas in which $75 \%$ of the total vertical vegetation density (number of plant contacts with a thin rod inserted vertically into the canopy) was found at heights $<10 \mathrm{~cm}$, compared to $63 \%$ in non-use areas (Bicak 1977). Preference for areas in which vegetation density is concentrated near ground level may be important in terms of the feeding behavior of Long-billed Curlews or their ability to see potential predators. In the Oklahoma Panhandle, curlews were usually observed in areas with clay loam soils on $0-1 \%$ slopes (Shackford 1987).

Curlews forage in grasslands, cultivated fields, stubble fields, wet meadows, prairie dog (Cynomys) colonies, and occasionally along wetland margins (Silloway 1900, Salt and Wilk 1958, Johnsgard 1980, Shackford 1987). During the incubation period in southwestern Idaho, Long-billed Curlew's prey-capture rate was higher in areas with short grass even though prey density was higher in areas with tall grass (vegetation measurements, prey densities, and capture rates were not given) (Bicak et al. 1982, Bicak 1983). Pre-laying female curlews in western Idaho foraged in shortgrass pasture within their territories during years when vegetation was short (3.6-9.7 cm tall) (Redmond 1986). However, during a year when vegetation was dense and tall (12-15.7 cm tall, with areas as high as $40 \mathrm{~cm}$ tall) due to abundant precipitation, curlews flew as far as $10 \mathrm{~km}$ from their territories to forage. In southcentral Washington, Long-billed Curlews preferred to forage in areas with higher topographic diversity (ridges and small dunes) and higher plant species diversity than in flatter areas with more homogeneous vegetation (Allen 1980). Although breeding density also was higher in topographically diverse areas, most nests 
were placed on relatively flat ground (neither the proportion of nests nor the slope of the ground was given).

In the Platte River Valley of Nebraska, Long-billed Curlews nested at higher densities in wet meadows than in upland prairie (Faanes and Lingle 1995). Within the sandhill grasslands of Nebraska, proximity of mixed-grass uplands to wet meadows was the most important criterion in nest-site selection (Bicak 1977). Wet meadows were used for feeding, loafing, and fledging young and were aggressively defended (Bicak 1977). Curlews in Nebraska also nested on upland slopes of native vegetation near moist meadows that were used for foraging (Johnsgard 1980). In North Dakota, Long-billed Curlews nested on grazed mixed-grass and on shortgrass prairie (Stewart 1975). Curlews preferred gently rolling terrain with gravelly soils. Long-billed Curlews in central Montana nested on dry portions of the mixed-grass prairie, which were elevated above their surroundings and located near wet meadows (Silloway 1900). Grassy floodplains adjoining a creek provided nesting habitat in southeastern Colorado (Davis 1949).

In northern Utah, Long-billed Curlew nests were found in irrigated and non-irrigated grass pastures and on alkali flats (Sugden 1933, Forsythe 1972, Paton and Dalton 1994). Nests in that area were built in bunchgrasses, clumps of sedges (Carex spp.), stands of inland saltgrass (Distichlis spicata), or saltwort (Salicornia rubra) (Forsythe 1972).

Of 21 nests in southeastern Washington, 71\% were in areas dominated by a mixture of downy brome and Sandberg's bluegrass and 29\% were in areas dominated by downy brome alone (Allen 1980). All areas with downy brome and Sandberg's bluegrass were used for nesting, whereas there were areas which were not used for nesting that contained only downy brome. Preference for areas dominated by the two plant species was attributed to a lower percent coverage of live (7\%) and dead (65\%) downy brome in those areas than in areas dominated by downy brome alone (live: 14\%; dead: 92\%). Plant communities dominated by downy brome but containing substantial amounts of tumbling mustard (Sisymbrium altissimum), as well as other grass communities (e.g., wheatgrass [Agropyron spp.] communities), were not used for nesting. In northcentral Oregon, mean nest density was highest in downy brome and Sandberg's bluegrass, followed by bunchgrasses, dense forbs and shrubs, and antelope bitterbrush (Pampush 1980, Pampush and Anthony 1993).

In northcentral Oregon, several vegetation variables differed between nesting areas and non-nesting areas (Pampush 1980, Pampush and Anthony 1993). Compared to non-nesting areas, nesting areas had shorter vegetation (24 vs. $29 \mathrm{~cm}$ at non-nesting areas), grass with less variation in height, total vegetation with less variation in height, grass with higher vertical density ( 0.8 vs. 0.2 contacts $/ 5 \mathrm{~cm}$ height increment) in the $25-50 \mathrm{~cm}$ height increment, and shrubs with lower total vertical density ( 0.02 vs. 0.05 contacts $/ 5 \mathrm{~cm}$ height increment). Nest density within study areas was negatively correlated with vegetation height and vertical density; nest density was positively correlated with percent cover of bare ground and with the evenness of forb height. Depredation of eggs and chicks was high in habitats other than downy brome, possibly indicating that predators were more dense or nests were more vulnerable in those habitats. In Wyoming, hayfields and pastures with nests had lower percent grass cover (mean of 20 vs. 32\%), had greater forb cover (mean of 16 vs. 4\%), and were drier (45 vs. 3\% of random locations characterized as 'dry') than hayfields and pastures that had no nests (Cochran and Anderson 1987).

Although Long-billed Curlews select nest sites in areas with short vegetation, vegetation within 3-6 m of the nest may be taller than vegetation in the surrounding habitat patch (Cochran 
and Anderson 1987, Paton and Dalton 1994). In Utah, habitat patches containing nests had shorter vegetation (mean of $5.6 \mathrm{~cm}$ ) than random habitat patches (mean of $9.0 \mathrm{~cm}$ ), and more bare ground 6-15 $\mathrm{m}$ from the nest (mean of 34-36\%) than random patches (mean of 38-39\%) (Paton and Dalton 1994). At nest sites, however, vegetation $<3 \mathrm{~m}$ from the nest was taller (mean of $6.5 \mathrm{~cm}$ ) than vegetation 6-15 $\mathrm{m}$ (mean of 4.9-5.5 $\mathrm{cm}$ ) from the nest and there was less bare ground $<3 \mathrm{~m}$ from the nest (mean of 18\%) than $\geq 6 \mathrm{~m}$ from the nest (mean of 28-39\%). In Wyoming, nest sites were characterized by less bare ground and higher percent cover of grasses (values were not given) than random sites within hayfields and pastures that contained nests (Cochran and Anderson 1987).

Nests often are located near cowpies or other conspicuous objects, possibly for concealment (Silloway 1900, Bent 1962, King 1978, Johnsgard 1979, Allen 1980, Cochran and Anderson 1987). Additionally, nests often occur on hummocks, possibly to improve visibility of predators and to prevent flooding in otherwise level fields (Cochran and Anderson 1987). Of 59 nests in southcentral Washington, $37 \%$ were $30-100 \mathrm{~cm}$ from an object (e.g., big sagebrush [Artemisia tridentata] branches, rocks, dirt mounds, horse manure, metal cans, bunchgrasses), $31 \%$ were $\leq 30 \mathrm{~cm}$ from an object, $27 \%$ were immediately adjacent to an object, and only $5 \%$ were $>100 \mathrm{~cm}$ from an object (Allen 1980). Big sagebrush, antelope bitterbrush, trees, dried tumbleweeds (Salsola), dirt mounds, rocks, tree stumps, and fences were used as perches.

Habitat characteristics of the landscape surrounding nest sites also influence Long-billed Curlew populations (Maher 1973, King 1978, Allen 1980, Pampush 1980, Pampush and Anthony 1993). After eggs hatch, adults and broods continue to forage in shortgrass and mixedgrass habitats, but they increase their use of areas with more vegetative cover (e.g., cropland, stubble fields, and weedy areas) (Maher 1973, 1974; King 1978; Allen 1980; Pampush 1980; Pampush and Anthony 1993), particularly if vegetation is sparse at the nest site (Maher 1974). Use of areas with tall, dense vegetation in the Texas Panhandle and northcentral Oregon may have provided chicks with an important source of shade or concealment cover (King 1978, Pampush 1980, Pampush and Anthony 1993). In central South Dakota, Long-billed Curlews with chicks were reported in grass that was $18 \mathrm{~cm}$ tall (Spomer 1981). In Oklahoma, Longbilled Curlews with young were observed in cultivated fields, shortgrass prairie, and tame grassland (Shackford 1994). A table near the end of the account lists the specific habitat characteristics for Long-billed Curlews by study.

\section{Area requirements:}

In southwestern Idaho, curlew densities were positively correlated with size of the management unit and with amount of area within the management unit that contained vegetation $<10 \mathrm{~cm}$ tall (Bicak et al. 1982). Territory size averaged about 14 ha in the most densely populated areas, and an unoccupied buffer zone of 300-500 m existed around the edge of suitable habitat (Redmond et al. 1981). In southeastern Washington, areas with diverse topography and habitat (shrubby areas near the nest sites) supported smaller (6-8 ha) curlew territories than did open, flat, less diverse habitat, which supported larger (20 ha) territories (Allen 1980). An increase in the breeding population between years did not result in the reduction of territory size, but rather resulted in an increased use of marginal habitat. Allen suggested that the existing territories may have already reached a minimum size. 
After eggs hatch, adults and their broods often leave the nesting site. In southern Saskatchewan, one pair of adults with a brood was recorded $>6.5 \mathrm{~km}$ from the nest site $6 \mathrm{~d}$ after hatching (Maher 1974, Sadler and Maher 1976).

Brown-headed Cowbird brood parasitism:

No known records of brood parasitism by Brown-headed Cowbirds (Molothrus ater) exist.

Breeding-season phenology and site fidelity:

Long-billed Curlews arrive on the breeding grounds from about mid-March through May and depart for the wintering grounds from August to October (Silloway 1900, Sugden 1933, Salt and Wilk 1958, Bent 1962, Maher 1974, Stewart 1975, Allen 1980, Pampush 1980, Renaud 1980, Redmond et al. 1981, Bicak et al. 1982, Paton and Dalton 1994). In some areas, fall departure may begin as early as June or July (Maher 1973, King 1978, Allen 1980), especially by unsuccessful breeders (Allen 1980, Paton and Dalton 1994). Peak breeding season in North Dakota is early May through early June (Stewart 1975). A single renesting attempt following depredation of a first clutch was observed in southcentral Washington (Allen 1980). The second nest also was depredated following completion of the clutch. Historically occupied sites are reused by curlews every year, and some individual birds may reuse the same territories from year to year (McCallum et al. 1977; Allen 1980; Redmond and Jenni 1982,1986).

\section{Species’ response to management:}

Burning can improve habitat for Long-billed Curlews by removing shrubs and increasing habitat openness (Pampush and Anthony 1993). During the breeding season following a fall range fire, there was a $30 \%$ increase in the estimated curlew breeding density in western Idaho (Redmond and Jenni 1986).

Haying can be used to provide the short vegetation preferred by nesting curlews, but should be timed so that short vegetation is available early in the season and active nests are not damaged (Cochran and Anderson 1987). In northcentral Oregon, alfalfa (Medicago sativa) fields were used for foraging as long as vegetation remained $<30 \mathrm{~cm}$ tall (Pampush 1980, Pampush and Anthony 1993). In Alberta, however, Long-billed Curlews did not use haylands (Prescott 1997). In Wyoming hay meadows, cowpies from fall- and winter-pastured cattle were scattered with branches, logs, or harrows (Cochran and Anderson 1987). This practice, termed "dragging," was detrimental because curlews often built nests near cowpies. The practice generally has declined since the 1960's but still can be common locally.

Grazing can be beneficial if it provides suitably short vegetation, particularly during the pre-laying period (Bicak et al. 1982, Cochran and Anderson 1987). Timing and intensity of grazing treatments should be adjusted according to local climate and habitat characteristics (Bicak et al. 1982, Bock et al. 1993). Curlew response to grazing over large areas of mixedgrass and shortgrass prairie was variable, but response to grazing in shrubsteppe habitats was negative (Bock et al. 1993). In Nebraska, curlews were present on grazed areas and were absent from ungrazed areas (Cole and Sharpe 1976). Long-billed Curlews in southern Alberta used only continuously grazed mixed-grass pasture and were absent from mixed-grass pasture grazed in early summer, spring-grazed tame pasture, and deferred-grazed (grazed after 15 July) mixedgrass pasture (Prescott et al. 1993). In southwestern Idaho, areas grazed by sheep alone or sheep 
and cattle had higher densities of curlews than did areas grazed by cattle alone (Bicak et al. 1982). Pastures that included sheep in the grazing regime had more area of short grass (32\% of area sampled $<10 \mathrm{~cm}$ tall) than areas grazed by cattle alone (19\% of area sampled $<10 \mathrm{~cm}$ tall). Curlew density was negatively correlated with height and vertical density of vegetation. Height of vegetation was negatively correlated with grazing intensity and with animal stocking rates. Sheep were less likely than cattle to follow established routes through the grassland, and thus sheep trampled and reduced the amount of dead vegetation to a greater extent than did cattle. However, Sugden (1933) cautioned that sheep are more likely to trample nests than cattle. In northwestern South Dakota, Long-billed Curlews were seen either in pastures with cattle or in unoccupied pasture; no curlews were observed in pastures with sheep (Timken 1969). In Idaho, neither cattle nor sheep could graze dense stands of perennial wheatgrasses, such as crested wheatgrass (Agropyron cristatum), to a height that was usable by curlews (Bicak et al. 1982). Long-billed Curlews preferred recently grazed areas and did not use areas that had not been grazed for $>1 \mathrm{yr}$. Rotational and deferred grazing may provide suitable habitat, but year-long grazing was not recommended. In Wyoming, nests in areas that were grazed during the incubation period had lower hatching success rates than nests in ungrazed areas (Cochran and Anderson 1987). Of 119 nests in western Idaho, 4.2\% were lost to trampling by livestock (Redmond and Jenni 1986).

Long-billed Curlews prefer grazed prairie, but will forage and occasionally even nest in cropland, including fallow fields, forage crops, and grain crops (McCallum et al. 1977, Pampush 1980, Renaud 1980, Cochran and Anderson 1987, Pampush and Anthony 1993). However, Renaud (1980) reported that curlews avoided large cultivated areas in Saskatchewan. In the Platte River Valley of Nebraska, conversion of upland prairie to cropland had a negative impact on curlews through the destruction of nesting habitat (Faanes and Lingle 1995). Long-billed Curlews in the Oklahoma Panhandle frequently used areas with a mix of shortgrass pasture and cropland, which often was planted to wheat (Shackford 1987). In Alberta, Long-billed Curlews were more common in areas of mixed-grass prairie than in cultivated areas (Owens and Myres 1973). In central South Dakota, Long-billed Curlew adults were observed in a bare, disced field (Spomer 1981). The only two nests found in cropland during a 3-yr Oklahoma study were destroyed by agricultural operations (Shackford 1994). Researchers suggested that Long-billed Curlews may experience better nesting success in wheat fields than in fields that are being prepared for plowing. Cochran and Anderson (1987) suggested that, although hayfields in Wyoming that had been cultivated may provide suitable vegetation and bare ground, they lacked elevated mounds and hummocks preferred for nesting. Nests in hayfields and pastures that were fertilized had lower success rates than nests in unfertilized fields, presumably due to disturbance by mechanical field operations.

In Alberta, Saskatchewan, and Manitoba, Long-billed Curlews were present on grasslands enrolled in the Permanent Cover Program (PCP) (McMaster and Davis 1998). PCP was a Canadian program that paid farmers to seed highly erodible land to perennial grassland cover; it differed from CRP in the United States in that haying and grazing were allowed annually in PCP.

Pesticides can be detrimental to Long-billed Curlews (Blus et al. 1985). Three Longbilled Curlews suffering convulsions or displaying erratic behavior were collected in northeastern Oregon. One male curlew appeared to have died of dieldrin poisoning and another of chlordane poisoning. The third, a female, may have sustained lethal injuries as a result of 
impairment from poisoning. Seven eggs collected in the same region all contained low concentrations of dichlorodiphenyltrichloroethane (DDT) metabolites, and some (numbers not given) contained low concentrations of polychlorinated biphenyls and chlordane metabolites. The authors suggested that concentrations of contaminants in the eggs were too low to influence the reproductive success of Long-billed Curlews substantially.

\section{Management Recommendations:}

Prevent conversion of upland prairie to cropland (Faanes and Lingle 1995).

Protect breeding habitat of curlews from detrimental human activities, such as vehicular use, researcher disturbance, and shooting (Sugden 1933, Redmond and Jenni 1986). In Saskatchewan, abandonment of breeding sites by Long-billed Curlews was attributed to researcher disturbance (Maher 1973, 1974).

Habitat areas need to be $\geq 3$ times as large as a Long-billed Curlew territory, which averages about 14 ha, in order for curlews to use them, because of an unoccupied buffer strip 300-500 m wide around the edge of suitable habitat (Redmond et al. 1981).

Tall, dense residual vegetation should be removed before the pre-laying period (March to April) so that adults do not have to leave their territories to forage (Redmond 1986; R. L. Redmond, University of Montana, Missoula, Montana, pers. comm.). Removal of residual vegetation is especially important after years of above-normal precipitation. Haying and grazing can be used to provide the short vegetation and reduced vertical plant density preferred by nesting curlews, but should be timed so that short vegetation is available early in the season (Cochran and Anderson 1987). In southwestern Idaho, curlews avoided areas that had not been grazed within the past year (Bicak et al. 1982).

Burn areas where fire will improve habitat by reducing shrub coverage and increasing habitat openness (Redmond and Jenni 1986, Pampush and Anthony 1993). During the breeding season following a fall range fire in western Idaho, the estimated curlew breeding density increased 30\% (Redmond and Jenni 1986).

Adjust timing and intensity of grazing treatment according to environmental factors (Bicak et al. 1982, Cochran and Anderson 1987, Bock et al. 1993).

Avoid grazing during the incubation period; in Wyoming, nests in areas that were grazed during incubation had lower hatching success rates than nests in other areas (Cochran and Anderson 1987).

In westcentral Wyoming, do not drag hayfields to break up cowpies; Long-billed Curlews prefer to nest near cowpies (Cochran and Anderson 1987). However, in Idaho, curlews did not show a preference for nesting near cowpies, and R. L. Redmond (pers. comm.), suggested that dragging 
may be acceptable if it occurs after the breeding season when eggs or chicks are no longer vulnerable. 
Table. Long-billed Curlew habitat characteristics.

\begin{tabular}{|c|c|c|c|}
\hline Author(s) & Location(s) & Habitat(s) Studied* & Species-specific Habitat Characteristics \\
\hline Allen 1980 & Washington & $\begin{array}{l}\text { Cropland, } \\
\text { shrubsteppe }\end{array}$ & $\begin{array}{l}\text { Preferred to forage in dune and ridge areas where topographic } \\
\text { and vegetational diversity were high; most nests were on } \\
\text { relatively flat ground; of } 59 \text { nests, } 5 \% \text { were }>100 \mathrm{~cm} \text { from an } \\
\text { object, } 37 \% \text { were } 30-100 \mathrm{~cm} \text { from an object, } 31 \% \text { were } \leq 30 \mathrm{~cm} \\
\text { from an object, and } 27 \% \text { abutted an object (e.g., big sagebrush } \\
\text { [Artemisia tridentata] limbs, rocks, dirt mounds, horse manure, } \\
\text { metal cans, bunchgrasses); preferred to nest ( } 71 \% \text { of } 21 \text { nests) } \\
\text { in areas dominated by downy brome (Bromus tectorum) and } \\
\text { Sandberg's bluegrass (Poa sandbergii) rather than in areas } \\
\text { dominated by downy brome alone ( } 29 \% \text { of nests); did not nest } \\
\text { in stands of downy brome containing substantial amounts of } \\
\text { tumbling mustard (Sisymbrium altissimum), nor in areas } \\
\text { dominated by wheatgrasses (Agropyron spp.); mean vegetation } \\
\text { values at nest sites in downy brome/Sandberg's bluegrass were } \\
<10 \text { cm downy brome height, } 20 \text { cm Sandberg's bluegrass } \\
\text { height, } 6.7 \% \text { coverage of live downy brome, } 65 \% \text { coverage of } \\
\text { dead downy brome, } 17 \% \text { coverage of live Sandberg's } \\
\text { bluegrass, and } 4.6 \% \text { coverage of dead Sandberg's bluegrass; } \\
\text { mean coverage values at nest sites in areas dominated by } \\
\text { downy brome were } 14 \% \text { coverage of live downy brome and } \\
92 \% \text { coverage of dead downy brome }\end{array}$ \\
\hline Bent 1962 & Rangewide & $\begin{array}{l}\text { Idle mixed-grass, idle } \\
\text { shortgrass, mixed- } \\
\text { grass pasture, } \\
\text { shortgrass pasture }\end{array}$ & $\begin{array}{l}\text { Required large, open prairie expanses; nested on grazed } \\
\text { rangeland and in damp, grassy hollows or slopes near bodies of } \\
\text { water }\end{array}$ \\
\hline Bicak 1977 & Nebraska & Mixed-grass hayland, & $\begin{array}{l}\text { Areas used by curlews had } 75 \% \text { of total vertical vegetation } \\
\text { density }<10 \mathrm{~cm} \text { high, compared to } 63 \% \text { in non-use areas; }\end{array}$ \\
\hline
\end{tabular}




\begin{tabular}{|c|c|c|c|}
\hline & & mixed-grass pasture & $\begin{array}{l}\text { proximity of nest sites to foraging meadows was more } \\
\text { important in nest site selection than vegetation characteristics }\end{array}$ \\
\hline Bicak et al. 1982 & Idaho & $\begin{array}{l}\text { Shortgrass/tame } \\
\text { pasture, tame pasture }\end{array}$ & $\begin{array}{l}\text { Used areas of short, recently grazed vegetation; curlew density } \\
\text { was positively correlated with size of management unit, annual } \\
\text { total animal unit months, and area of vegetation }<10 \mathrm{~cm} \text { tall; } \\
\text { areas grazed by sheep alone or by sheep and cattle had more } \\
\text { area of short grass ( } 32 \% \text { of area sampled was }<10 \mathrm{~cm} \text { tall) and } \\
\text { higher densities of curlews than did areas grazed by cattle alone } \\
\text { (19\% of area sampled was }<10 \mathrm{~cm} \text { tall); did not use areas that } \\
\text { had not been grazed for }>1 \mathrm{yr}\end{array}$ \\
\hline $\begin{array}{l}\text { Cochran and Anderson } \\
1987\end{array}$ & Wyoming & $\begin{array}{l}\text { Shortgrass hayland, } \\
\text { shortgrass pasture, } \\
\text { tame hayland, tame } \\
\text { pasture, woodland }\end{array}$ & $\begin{array}{l}\text { Preferred irrigated native hayland and pasture over tame } \\
\text { hayland and pasture; nested in pastures and hayfields that had } \\
\text { lower mean percent grass cover ( } 20 \text { vs. } 32 \% \text { ), higher mean } \\
\text { percent forb cover ( } 16 \text { vs. } 3.5 \% \text { ), and were drier ( } 45 \text { vs. } 3 \% \text { of } \\
\text { random locations characterized as 'dry') than unused pastures } \\
\text { and hayfields; within pastures and hayfields containing nests, } \\
\text { nest sites had less bare ground and higher percent cover of } \\
\text { grasses (values not given) than random sites; preferred to nest } \\
\text { on hummocks } \geq 2.5 \text { cm above the immediate surroundings; } \\
\text { percent coverages in native hayland and pasture were } 24 \% \\
\text { grass, } 24 \% \text { sedge (Carex), } 23 \% \text { bare ground, } 9.9 \% \text { rush } \\
\text { (Juncus), } 7.8 \% \text { forbs, and } 0.8 \% \text { moss (Latin name not given) }\end{array}$ \\
\hline Cole and Sharpe 1976 & Nebraska & Idle, pasture & $\begin{array}{l}\text { Were present on areas that were grazed, and absent from idle } \\
\text { areas }\end{array}$ \\
\hline \multirow[t]{2}{*}{$\begin{array}{l}\text { Faanes and Lingle } \\
1995\end{array}$} & Nebraska & $\begin{array}{l}\text { Idle mixed-grass, idle } \\
\text { shortgrass, idle } \\
\text { tallgrass, wet } \\
\text { meadow }\end{array}$ & Nested at higher densities in wet meadow than in upland prairie \\
\hline & & Shrubsteppe, & Nests were found in irrigated and non-irrigated grass pastures \\
\hline
\end{tabular}




\begin{tabular}{|c|c|c|c|}
\hline Forsythe 1972 & Utah & shrubsteppe pasture & $\begin{array}{l}\text { and salt flats; nests were built in bunchgrasses, clumps of } \\
\text { sedges (Carex spp.), and stands of inland saltgrass (Distichlis } \\
\text { spicata), or saltwort (Salicornia rubra) }\end{array}$ \\
\hline Gratto-Trevor 1999 & Alberta & $\begin{array}{l}\text { Shortgrass pasture, } \\
\text { wetland }\end{array}$ & $\begin{array}{l}\text { Were more common on dry transects (a dry transect was } \\
\text { defined as intersecting wetlands along } \leq 5 \% \text { of its length) than } \\
\text { on wet transects }\end{array}$ \\
\hline Graul 1971 & Colorado & Shortgrass & $\begin{array}{l}\text { Nested in shortgrass prairie at the edge of a valley and near a } \\
\text { hill; nest was lined with buffalo grass (Buchloe sp.) and lichen } \\
\text { (Parmelia molliuscula); vegetation surrounding the nest was } \\
\text { buffalo grass, blue grama (Bouteloua gracilis), and plains } \\
\text { prickly pear (Opuntia polyacantha) }\end{array}$ \\
\hline Johnsgard 1979, 1980 & $\begin{array}{l}\text { Colorado, } \\
\text { Kansas, } \\
\text { Nebraska, } \\
\text { New Mexico, } \\
\text { North Dakota, } \\
\text { Oklahoma, } \\
\text { South Dakota, } \\
\text { Texas }\end{array}$ & $\begin{array}{l}\text { Cropland, idle } \\
\text { mixed-grass, idle } \\
\text { shortgrass, idle } \\
\text { tallgrass, mixed-grass } \\
\text { pasture, tallgrass } \\
\text { pasture, tame } \\
\text { hayland, wet meadow }\end{array}$ & $\begin{array}{l}\text { Nested on shortgrass plains on gently rolling terrain or on } \\
\text { upland prairie slopes; in the sandhill grasslands region, close } \\
\text { proximity to wet meadows was important in nest-site selection; } \\
\text { nests frequently were placed next to cowpies; used wet } \\
\text { meadows as foraging areas }\end{array}$ \\
\hline \multirow[t]{2}{*}{$\begin{array}{l}\text { Kantrud and Kologiski } \\
1982\end{array}$} & $\begin{array}{l}\text { Colorado, } \\
\text { Montana, } \\
\text { Nebraska, } \\
\text { North Dakota, } \\
\text { South Dakota, } \\
\text { Wyoming }\end{array}$ & $\begin{array}{l}\text { Mixed-grass pasture, } \\
\text { shortgrass pasture, } \\
\text { shrubsteppe }\end{array}$ & $\begin{array}{l}\text { Preferred lightly grazed areas with aridic ustoll and aridic } \\
\text { borollic soils, and heavily grazed areas with typic ustoll soils; } \\
\text { plants that were more common than average within nesting } \\
\text { habitat included clubmoss (Selaginella densa), blue grama, } \\
\text { fringed sagewort (Artemisia frigida), and golden aster } \\
\text { (Chrysopsis villosa); other common plants within breeding } \\
\text { habitat included bluebunch wheatgrass (Pseudoroegneria } \\
\text { spicata), prairie sandreed (Calamovilfa longifolia), and Idaho } \\
\text { fescue (Festuca idahoensis) }\end{array}$ \\
\hline & Colorado, & Cropland, idle, & Six of seven nests were in areas dominated by buffalo grass \\
\hline
\end{tabular}




\begin{tabular}{|c|c|c|c|}
\hline King 1978 & Texas & $\begin{array}{l}\text { mixed-grass pasture, } \\
\text { sand-sage grassland, } \\
\text { shortgrass pasture }\end{array}$ & $\begin{array}{l}\text { (Buchloe dactyloides) and blue grama; one nest was in an area } \\
\text { dominated by sand dropseed (Sporobolus cryptandrus); six of } \\
\text { seven nests were within } 20 \mathrm{~cm} \text { of a cowpie; mean vegetation } \\
\text { height at nests was } 11 \mathrm{~cm} \text {; mean vegetation cover at nests was } \\
72 \% \text {; at } 3 \mathrm{~m} \text { from nests, mean vegetation height was } 20.6 \mathrm{~cm} \text {; } \\
\text { did not use areas dominated by sand sagebrush (Artemisia } \\
\text { filifolia) for nesting or foraging; } 39 \% \text { of curlew observations } \\
\text { occurred within } 400 \text { m of standing water (irrigation, } \\
\text { stockponds); used shortgrass, mixed-grass, and weedy areas in } \\
\text { slightly greater proportions ( } 75 \% \text { of } 354 \text { observations) than } \\
\text { their availability ( } 67 \% \text { of the landscape); use of areas with high } \\
\text { structural diversity increased following hatching of eggs }\end{array}$ \\
\hline McCallum et al. 1977 & Colorado & $\begin{array}{l}\text { Idle, mixed-grass, } \\
\text { shortgrass }\end{array}$ & $\begin{array}{l}\text { Preferred to nest in shortgrass prairie; occasionally nested in } \\
\text { fallow fields; } 41 \% \text { of } 63 \text { curlew observations were } \leq 91 \mathrm{~m} \text { from } \\
\text { water and } 68 \% \text { were } \leq 403 \mathrm{~m} \text { from water; avoided tall } \\
\text { (measurements not provided) vegetation }\end{array}$ \\
\hline $\begin{array}{l}\text { McMaster and Davis } \\
1998\end{array}$ & $\begin{array}{l}\text { Alberta, } \\
\text { Manitoba, } \\
\text { Saskatchewan }\end{array}$ & $\begin{array}{l}\text { Cropland, Permanent } \\
\text { Cover Program } \\
\text { (PCP; idle tame, } \\
\text { tame hayland, tame } \\
\text { pasture) }\end{array}$ & $\begin{array}{l}\text { Present in both cropland and PCP grassland; PCP cover } \\
\text { included combinations of wheatgrasses, brome (Bromus spp.), } \\
\text { and alfalfa (Medicago spp.) }\end{array}$ \\
\hline $\begin{array}{l}\text { Owens and Myres } \\
1973\end{array}$ & Alberta & $\begin{array}{l}\text { Cropland, idle } \\
\text { mixed-grass, mixed- } \\
\text { grass hayland, } \\
\text { mixed-grass pasture }\end{array}$ & $\begin{array}{l}\text { Were more common in areas of mixed-grass than in cultivated } \\
\text { areas }\end{array}$ \\
\hline $\begin{array}{l}\text { Pampush 1980, } \\
\text { Pampush and Anthony } \\
1993\end{array}$ & Oregon & $\begin{array}{l}\text { Cropland, idle, idle } \\
\text { shortgrass, idle tame, } \\
\text { shortgrass/tame } \\
\text { pasture, shrubsteppe, }\end{array}$ & $\begin{array}{l}\text { Highest mean densities of nests occurred in areas of downy } \\
\text { brome with patches of Sandberg's bluegrass intermixed; } \\
\text { avoided areas of antelope bitterbrush (Purshia tridentata) and } \\
\text { areas with dense forbs; nest density was negatively correlated }\end{array}$ \\
\hline
\end{tabular}




\begin{tabular}{|c|c|c|c|}
\hline & & tame hayland & $\begin{array}{l}\text { with vegetation height and vertical density; foraged in fallow } \\
\text { fields and alfalfa (Medicago sativa) as long as vegetation was } \\
<30 \mathrm{~cm} \text { tall; compared to non-nest areas, nest areas were } \\
\text { associated with shorter vegetation ( } 24 \mathrm{~cm} \text { vs. } 29 \mathrm{~cm} \text { at non-nest } \\
\text { areas), grass with less variation in height, total vegetation with } \\
\text { less variation in height, grass with higher vertical density ( } 0.8 \\
\text { contacts vs. } 0.2 \text { contacts } / 5 \mathrm{~cm} \text { height increment) in the } 25-50 \\
\text { cm height increment, and shrubs with lower total vertical } \\
\text { density ( } 0.02 \text { contacts vs. } 0.05 \text { contacts } / 5 \mathrm{~cm} \text { height increment) }\end{array}$ \\
\hline Paton and Dalton 1994 & Utah & $\begin{array}{l}\text { Shrubsteppe pasture, } \\
\text { wetland }\end{array}$ & $\begin{array}{l}\text { Habitat patches containing nests had shorter vegetation (mean } \\
\text { of } 5.6 \mathrm{~cm} \text { ) than random habitat patches (mean of } 9.0 \mathrm{~cm} \text { ), and } \\
\text { more bare ground } 6-15 \mathrm{~m} \text { from the nest (mean of } 34-36 \% \text { ) than } \\
\text { random patches (mean of } 38-39 \% \text { ); at nest sites, vegetation }<3 \\
\mathrm{~m} \text { from the nest was taller (mean of } 6.5 \mathrm{~cm} \text { ) than vegetation } 6 \text { - } \\
15 \mathrm{~m} \text { from the nest (mean of } 4.9-5.5 \mathrm{~cm} \text { ) and there was less } \\
\text { bare ground }<3 \mathrm{~m} \text { from the nest (mean of } 18 \% \text { ) than } \geq 6 \mathrm{~m} \text { from } \\
\text { the nest (mean of } 28-39 \% \text { ) }\end{array}$ \\
\hline Prescott 1997 & Alberta & $\begin{array}{l}\text { Cropland, hayland, } \\
\text { idle, idle mixed-grass } \\
\text { pasture, shrubland, } \\
\text { tame pasture, } \\
\text { woodland }\end{array}$ & $\begin{array}{l}\text { Occurred (in decreasing order of abundance) in mixed-grass, } \\
\text { mixed-grass within sandhills areas, planted cropland, and } \\
\text { hayfields; were absent from fallow cropland, stubble fields, } \\
\text { riparian areas, upland shrubland, and upland areas of deciduous } \\
\text { trees }\end{array}$ \\
\hline Prescott et al. 1993 & Alberta & $\begin{array}{l}\text { Mixed-grass pasture, } \\
\text { tame pasture, } \\
\text { wetland, wetland } \\
\text { (restored) }\end{array}$ & $\begin{array}{l}\text { Were present only in continuously grazed mixed-grass pasture; } \\
\text { absent from early summer-grazed mixed-grass pasture, spring- } \\
\text { grazed tame pasture, and deferred-grazed (grazed after } 15 \text { July) } \\
\text { mixed-grass pasture }\end{array}$ \\
\hline Redmond 1986 & Idaho & $\begin{array}{l}\text { Cropland, shortgrass } \\
\text { pasture }\end{array}$ & $\begin{array}{l}\text { Nested in shortgrass pasture; foraged in shortgrass pasture } \\
\text { when vegetation was sparse ( } 3.6 \text { to } 9.7 \mathrm{~cm} \text { tall) but traveled up } \\
\text { to } 10 \mathrm{~km} \text { from nesting sites to forage in agricultural areas when }\end{array}$ \\
\hline
\end{tabular}




\begin{tabular}{|l|l|l|l|}
\hline & & & $\begin{array}{l}\text { vegetation was dense (12 to 15.7 cm tall with areas 40 cm tall) } \\
\text { due to abundant precipitation }\end{array}$ \\
\hline Shackford 1987 & Oklahoma & $\begin{array}{l}\text { Colonies of } \\
\text { burrowing mammals, } \\
\text { cropland, idle, } \\
\text { shortgrass pasture }\end{array}$ & $\begin{array}{l}\text { Used native pastures near cultivated fields (mostly planted to } \\
\text { wheat); areas that were used had clay loam soils on 0-1\% } \\
\text { slopes; curlews with young foraged in prairie dog (Cynomys) } \\
\text { colonies }\end{array}$ \\
\hline Shackford 1994 & Oklahoma & $\begin{array}{l}\text { Cropland, shortgrass, } \\
\text { tame }\end{array}$ & $\begin{array}{l}\text { Curlews were observed in cropland, in shortgrass prairie, and in } \\
\text { tame grassland; two nests were found in cultivated fields }\end{array}$ \\
\hline Stewart 1975 & North Dakota & $\begin{array}{l}\text { Idle shortgrass, } \\
\text { mixed-grass pasture }\end{array}$ & $\begin{array}{l}\text { Used shortgrass prairie and mixed-grass pasture; some areas of } \\
\text { shortgrass prairie that were used had prickly pear cactus } \\
\text { Opuntia) and an open shrub layer composed of big sagebrush } \\
\text { and silver sagebrush (Artemisia cana); preferred gently rolling } \\
\text { terrain with gravelly soils }\end{array}$ \\
\hline Sugden 1933 & Utah & Pasture, wetland & $\begin{array}{l}\text { Preferred flat, open country of alkali flats and wetlands around } \\
\text { the Great Salt Lake }\end{array}$ \\
\hline Timken 1969 & South Dakota & Pasture & $\begin{array}{l}\text { Curlews were noted in idle pasture and in cattle pasture, but not } \\
\text { in sheep pasture }\end{array}$ \\
\hline
\end{tabular}

*In an effort to standardize terminology among studies, various descriptors were used to denote the management or type of habitat. "Idle" used as a modifier (e.g., idle tallgrass) denotes undisturbed or unmanaged (e.g., not burned, mowed, or grazed) areas. "Idle" by itself denotes unmanaged areas in which the plant species were not mentioned. Examples of "idle" habitats include weedy or fallow areas (e.g., oldfields), fencerows, grassed waterways, terraces, ditches, and road rights-of-way. "Tame" denotes introduced plant species (e.g., smooth brome [Bromus inermis]) that are not native to North American prairies. "Hayland" refers to any habitat that was mowed, regardless of whether the resulting cut vegetation was removed. "Burned" includes habitats that were burned intentionally or accidentally or those burned by natural forces (e.g., lightning). In situations where there are two or more descriptors (e.g., idle tame hayland), the first descriptor modifies the following descriptors. For example, idle tame hayland is habitat that is usually mowed annually but happened to be undisturbed during the year of the study. 


\section{LITERATURE CITED}

Allen, J. N. 1980. The ecology and behavior of the Long-billed Curlew in southeastern Washington. Wildlife Monographs 73. 65 pages.

Bent, A. C. 1962. Life histories of North American shorebirds. Part 2. Dover Publications, Inc., New York, New York. 602 pages.

Bicak, T. K. 1977. Some eco-ethological aspects of a breeding population of Long-billed Curlews (Numenius americanus) in Nebraska. M.S. thesis. University of Nebraska, Omaha, Nebraska. 42 pages.

Bicak, T. K. 1983. Vegetative interference: a factor affecting Long-billed Curlew (Numenius americanus) foraging success. Wader Study Group Bulletin 39:57.

Bicak, T. K., R. L. Redmond, and D. A. Jenni. 1982. Effects of grazing on Long-billed Curlew (Numenius americanus) breeding behavior and ecology in southwestern Idaho. Pages 7485 in J. M. Peek and P. D. Dalke, editors. Proceedings of the wildlife-livestock relationships symposium. University of Idaho, Forest, Wildlife and Range Experiment Station, Moscow, Idaho.

Blus, L. J., C. J. Henny, and A. J. Krynitsky. 1985. Organochlorine-induced mortality and residues in Long-billed Curlews from Oregon. Condor 87:563-565.

Bock, C. E., V. A. Saab, T. D. Rich, and D. S. Dobkin. 1993. Effects of livestock grazing on Neotropical migratory landbirds in western North America. Pages 296-309 in D. M. Finch and P. W. Stangel, editors. Status and management of Neotropical migratory birds. U.S.D.A. Forest Service, General Technical Report RM-229.

Cochran, J. F., and S. H. Anderson. 1987. Comparison of habitat attributes at sites of stable and declining Long-billed Curlew populations. Great Basin Naturalist 47:459-466.

Cole, T., and R. S. Sharpe. 1976. The effects of grazing management on a sandhills prairie community. III. Breeding bird density and diversity. Proceedings of the Nebraska Academy of Science Affiliated Society 86:12.

Davis, W. B. 1949. Long-billed Curlew breeding in Colorado. Auk 66:202.

Eldridge, J. 1992. Management of habitat for breeding and migrating shorebirds in the Midwest. U.S. Fish and Wildlife Service Leaflet 13.2.14. 6 pages.

Faanes, C. A., and G. R. Lingle. 1995. Breeding birds of the Platte River Valley of Nebraska. Jamestown, ND: Northern Prairie Wildlife Research Center home page. http://www.npwrc.usgs.gov/resource/distr/birds/platte/platte.htm (Version 16JUL97).

Forsythe, D. M. 1972. Observations on the nesting biology of the Long-billed Curlew. Great Basin Naturalist 32:88-90. 
Gratto-Trevor, C. 1999. Use of managed and natural wetlands by upland breeding shorebirds in southern Alberta. Pages 252-259 in Proceedings of the fifth prairie conservation and endangered species conference. Natural History Occasional Paper 24. Provincial Museum of Alberta, Edmonton, Alberta.

Graul, W. D. 1971. Observations at a Long-billed Curlew nest. Auk 88:182-184.

Johnsgard, P. A. 1979. Birds of the Great Plains. University of Nebraska Press, Lincoln, Nebraska. 539 pages.

Johnsgard, P. A. 1980. A preliminary list of the birds of Nebraska and adjacent Plains states. University of Nebraska, Lincoln, Nebraska. 156 pages.

Kantrud, H. A., and R. L. Kologiski. 1982. Effects of soils and grazing on breeding birds of uncultivated upland grasslands of the northern Great Plains. U.S. Fish and Wildlife Service, Wildlife Research Report 15. 33 pages.

King, R. 1978. Habitat use and related behaviors of breeding Long-billed Curlews. M.S. thesis. Colorado State University, Fort Collins, Colorado. 69 pages.

Maher, W. J. 1973. Matador Project: Birds I. Population dynamics. Canadian Committee for the International Biological Programme, Matador Project, Technical Report 34. University of Saskatchewan, Saskatoon, Saskatchewan. 56 pages.

Maher, W. J. 1974. Matador Project: Birds II. Avifauna of the Matador area. Canadian Committee for the International Biological Programme, Matador Project, Technical Report 58. University of Saskatchewan, Saskatoon, Saskatchewan. 31 pages.

McCallum, D. A., W. D. Graul, and R. Zaccagnini. 1977. The breeding status of the Longbilled Curlew in Colorado. Auk 94:599-601.

McMaster, D. G., and S. K. Davis. 1998. Non-game evaluation of the Permanent Cover Program. Unpublished report. Saskatchewan Wetland Conservation Corporation, Regina, Saskatchewan. $75+$ pages.

National Geographic Society. 1987. Field guide to the birds of North America, second edition. National Geographic Society, Washington, D.C. 464 pages.

Owens, R. A., and M. T. Myres. 1973. Effects of agriculture upon populations of native passerine birds of an Alberta fescue grassland. Canadian Journal of Zoology 51:697-713.

Pampush, G. J. 1980. Breeding chronology, habitat utilization and nest-site selection of the Long-billed Curlew in northcentral Oregon. M.S. thesis. Oregon State University, Corvallis, Oregon. 49 pages.

Pampush, G. J., and R. G. Anthony. 1993. Nest success, habitat utilization and nest-site selection of Long-billed Curlews in the Columbia Basin, Oregon. Condor 95:957-967. 
Paton, P. W. C., and J. Dalton. 1994. Breeding ecology of Long-billed Curlews at Great Salt Lake, Utah. Great Basin Naturalist 54:79-85.

Prescott, D. R. C. 1997. Avian communities and NAWMP habitat priorities in the northern prairie biome of Alberta. NAWMP-029. Land Stewardship Centre of Canada, St. Albert, Alberta. 41 pages.

Prescott, D. R. C., R. Arbuckle, B. Goddard, and A. Murphy. 1993. Methods for the monitoring and assessment of avian communities on NAWMP landscapes in Alberta, and 1993 results. NAWMP-007. Alberta NAWMP Centre, Edmonton, Alberta. 48 pages.

Redmond, R. L. 1986. Egg size and laying date of Long-billed Curlews (Numenius americanus): implications for female reproductive tactics. Oikos 46:330-338.

Redmond, R. L., T. K. Bicak, and D. A. Jenni. 1981. An evaluation of breeding season census techniques for Long-billed Curlews (Numenius americanus). Studies in Avian Biology 6:197-201.

Redmond, R. L., and D. A. Jenni. 1982. Natal philopatry and breeding area fidelity of Longbilled Curlews (Numenius americanus): patterns and evolutionary consequences. Behavioral Ecology and Sociobiology 10:277-279.

Redmond, R. L., and D. A. Jenni. 1986. Population ecology of the Long-billed Curlew (Numenius americanus) in western Idaho. Auk 103:755-767.

Renaud, W. E. 1980. The Long-billed Curlew in Saskatchewan: status and distribution. Blue Jay 38:221-237.

Sadler, D. A., and W. J. Maher. 1976. Notes on the Long-billed Curlew in Saskatchewan. Auk 93:382-384.

Salt, W. R., and A. L. Wilk. 1958. The birds of Alberta. Department of Economic Affairs, Edmonton, Alberta. 295 pages.

Shackford, J. S. 1987. Nesting distribution and population census of Golden Eagles, Prairie Falcons, Mountain Plovers, and Long-billed Curlews in Cimarron County, Oklahoma. Unpublished report, George Miksch Sutton Avian Research Center, Inc., Bartlesville, Oklahoma. 28 pages.

Shackford, J. S. 1994. Nesting of Long-billed Curlews on cultivated fields. Bulletin of the Oklahoma Ornithological Society 27:17-20.

Silloway, P M. 1900. Notes on the Long-billed Curlew. Condor 2:79-82.

Spomer, R. 1981. Long-billed Curlews and Sprague’s Pipits near Pierre. South Dakota Bird Notes 33:78.

Stewart, R. E. 1975. Breeding birds of North Dakota. Tri-College Center for Environmental Studies, Fargo, North Dakota. 295 pages. 
Sugden, J. W. 1933. Range restriction of the Long-billed Curlew. Condor 35:3-9.

Timken, R. L. 1969. Notes on the Long-billed Curlew. Auk 86:750-751. 